\title{
Growth responses of planktonic ciliates in the genera Strobilidium and Strombidium
}

\author{
David J. S. Montagnes* \\ University of Washington, School of Oceanography, PO Box 357940, Seattle, Washington 98195-7940, USA
}

\begin{abstract}
Intrinsic growth and mortality rates need to be estimated to assess the potential for oligotrich ciliate populations to exploit prey populations, and since species specific differences exist, data for a variety of ciliates grazing on a variety of prey are also needed. In this paper, data are presented on the growth and mortality rates of 4 planktonic oligotrichs (2 Strobilidium species and 2 Strombidium species), at a number of prey concentrations. Growth and mortality data for these and other species in these 2 genera are reviewed. In general, these oligotrichs have maximum growth rates $\left(\mu, \mathrm{d}^{-1}\right)$ ranging from $\sim 0.3$ to 2.2 (at temperatures ranging from 6 to $31^{\circ} \mathrm{C}$ ); they have similar threshold concentrations (the food concentration where growth rate equals zero) of 10 to $100 \mathrm{ng} \mathrm{C} \mathrm{ml}^{-1}$; they have rapid mortality rates at sub-threshold concentrations (cells only survive 1 to $3 \mathrm{~d}$ ); and the range of food concentrations where the growth rate increases from zero to near its maximum is 20 to $300 \mathrm{ng} \mathrm{C} \mathrm{ml}{ }^{-1}$ Although generalities can be made about ciliates in these 2 genera, the data suggest that in terms of growth and mortality rates, planktonic oligotrichs cannot be considered a single functional group. There is, however, a need to predict 'typical' oligotrich growth rates. To this end, several formulae have been established to predict maximum growth rates from ciliate cell volume and ambient temperature. In this paper, the growth data for Strobilidium and Strombidium are reviewed and compared to the predicted values from formulae in the literature; the formula presented by Müller \& Geller (1993, Arch. Hydrobiol. 126: 315-327) appears to be the best preductor of maximum growth rate from cell volume and ambient temperature. Finally, based on the review of growth data for these 2 genera, some speculations are made as to how these ciliates may exploit prey populations in a planktonic environment composed of small-scale patches.
\end{abstract}

KEY WORDS: Growth rate - Mortality rate - Nanoplankton - Oligotrich Ciliate Plankton S Small-scale patches - Strobilidium - Strombidium

\section{INTRODUCTION}

Oligotrich ciliates in the genera Strobilidium and Strombidium are conspicuous components of the microzooplankton and may shunt a substantial portion of matter through planktonic food webs. Typically, 1 to 10 oligotrichs $\mathrm{ml}^{-1}$ occur in marine waters (Fenchel 1987 , Lynn \& Montagnes 1991), but the mechanisms which control oligotrich abundances are not well understood. Copepod predation may maintain a relatively constant abundance of ciliates (Nielsen \& Kiørboe 1994), but populations of oligotrichs and their prey at times fluctuate greatly, forming short-term 'blooms' (e.g. Andersen \& Sørensen 1986).

\footnotetext{
- Present address: Port Erin Marine Lab, Port Erin, Isle of Man IM9 6JA, United Kingdom
}

It may be that isolated ciliate populations regularly exploit very small patches in the plankton (e.g. Tiselius et al. 1993): such small-scale increases in abundance of ciliates have been observed (Nielsen et al. 1990, 1993). Therefore, although ciliate assemblages may appear to remain constant, there may be a succession of populations, governed largely by bottom-up control (Nielsen \& Kiørboe 1994). However, when conditions become unstable (e.g. zooplankton predation is reduced or algal prey blooms occur) blooms of oligotrichs may occur for periods ranging from hours to days (e.g. Smetacek 1981, 1984, Andersen \& Sorensen 1986 , Dale \& Dahl 1987, Montagnes et al. 1988a, Rassoulzadegan et al. 1988).

To assess the potential for ciliates to exploit transient prey patches, reliable estimates of growth rates are needed. Furthermore, since species specific differ- 
ences exist that could alter predator-prey dynamics (Montagnes 1993), data for a variety of ciliates grazing on a variety of prey are needed. In this paper, data are presented on the growth rate of 4 planktonic oligotrich clones, 2 in the genus Strobilidium and 2 in the genus Strombidium, at a number of prey concentrations. Numerical response curves (growth rate vs food concentration) were generated that indicate both the growth rates of the ciliates and their mortality rates, at concentrations where the ciliates are starving. These data will help assess the localized interaction of ciliates with their prey.

However, to model marine ecosystems on a larger scale, there is often a need to predict ciliate growth rates (e.g. to estimate the production of field populations for which no growth data are available). Several predictive formulae have been established for ciliates in general (e.g. Fenchel 1974, Finlay 1977, Montagnes et al. 1988a, Müller \& Geller 1993) and one for oligotrichs specifically (Nielsen \& Kiorboe 1994). Montagnes et al. (1988a), Müller \& Geller (1993), and Nielsen \& Kiørboe (1994) all used multiple regressions involving ciliate cell volume and ambient temperature to predict growth rate. In this paper, the growth data for Strobilidium (Strob.) and Strombidium (Strom.) are reviewed and compared to the predicted values from these 3 formulae to determine which formula is the best predictor of maximum growth rate.

\section{METHODS AND MATERIALS}

General culturing. Isolation and identification: Strobilidium neptuni Montagnes \& Taylor, 1994 (Fig. 1a), Strob. veniliae Montagnes \& Taylor, 1994 (Fig. 1b), Strombidium capitatum (Leegaard, 1915) Kahl, 1932 (Fig. 2a), and Strom. siculum (Leegaard, 1915) Montagnes \& Taylor, 1994 (Fig. 2b) were isolated from coastal subsurface British Columbian (Canada) waters, and clonal cultures were established (see Montagnes \& Taylor 1994). Cultures were not made bacteria-free, and bacteria were not considered to be a food source.

Note that Strobilidium neptuni is morphologically nearly identical to Strob. spiralis, studied extensively by Rassoulzadegan (1982) and Jonsson (1986). Verity (1991) also studied 'Strob. spiralis', but his species was substantially smaller than the typical size of Strob. spiralis ( $P$. Verity pers. comm., Lynn \& Montagnes 1988). Verity's species was identified by D. H. Lynn. However, we now recognize that the genus Strobilidium exhibits subtle variations that distinguish different species, many of which look like Strob. spiralis (D. H Lynn pers. comm., Montagnes \& Taylor 1994), and it is possible that Verity's (1991) species of Strobilidium was misidentified (D. H. Lynn pers. comm.).
Preferred prey: Prior to the numerical response experiments, all 4 species of ciliates were cultured on a combination of the nanophytoflagellates Isochrysis galbana, Chroomonas salina, and Rhodomonas lens (Table 1). Subsequently, the ciliates were tested for growth on all combinations of these prey species: the ciliates grew on a number of prey combinations (Table 2). Strombidium siculum also grew well. on the small (4 $\mathrm{mm}$ ) diatom Thalassiosira pseudonana (Table 1). Food type has previously been shown to affect ciliate growth (see Repak 1983, Gifford 1985, Verity \& Villareal 1986, Skogstad et al. 1987).

Growth rates. Numerical response: The ciliates were grown on prey that elicited a maximum growth response (Table 2). When possible, a single prey species was preferentially used over multiple prey: Strobilidium neptuni was grown on Chroomonas salina; Strob. veniliae was grown on a $1: 1$ combination of Isochrysis galbana and C. salina; Strombidium capitatum was grown on a 1:1 combination of C. salina and I. galbana; in one experiment, Strom. siculum was grown on a 1:1:1 combination of I. galbana, C. salina, and Rhodomonas lens; and in a second experiment, Strom. siculum was grown on Thalassiosira pseudonana alone. Prey cell sizes, carbon quotas, and nitrogen quotas are presented in Table 1. During growth experiments where more than one prey species was used, relative changes in prey abundance were not measured; it was assumed that the ciliates consumed these prey at equal rates, and calculations of carbon from prey numbers were determined as the mean of prey species.

The prey were cultured separately in $150 \mathrm{ml}$ glass flasks at $16^{\circ} \mathrm{C}$ on a $14: 10 \mathrm{~h}$ light:dark cycle at 50 to $100 \mu \mathrm{mol}$ photons $\mathrm{m}^{-2} \mathrm{~s}^{-1}$ in enriched natural seawater (NEPCC medium; see Montagnes \& Taylor 1994), and for experiments they were harvested in exponential growth phase. Prior to the experiments, the ciliates were maintained with the prey in NEPCC medium in 6 -well $20 \mathrm{ml}$ plastic tissue culture plates

Table 1 Cell quotas and sizes for the phytoplankton prey species: measurements were made hy Montagnes et al (1994). All cultures were provided by the Northeast Pacific Culture Collection, NEPCC, Department of Oceanography, University of British Columbia, Vancouver, British Columbia, Canada

\begin{tabular}{|lrrrrr|}
\hline Species & $\begin{array}{c}\text { NEPCC } \\
\text { clone }\end{array}$ & $\begin{array}{c}\text { Length } \\
(\mu \mathrm{m})\end{array}$ & $\begin{array}{c}\text { Width } \\
(\mu \mathrm{m})\end{array}$ & $\begin{array}{c}\mathrm{pg} \mathrm{C} \\
\left(\mathrm{cell}^{-1}\right)\end{array}$ & $\begin{array}{c}\mathrm{pg} N \\
\left(\mathrm{cell}^{-1}\right)\end{array}$ \\
\hline Chroomonas salina & 275 & 11.0 & 6.5 & 32.0 & 8.9 \\
$\begin{array}{l}\text { Isochrysis galbana } \\
\text { Rhodomonas lens }\end{array}$ & 533 & 5.5 & 5.5 & 7.0 & 1.2 \\
$\begin{array}{l}\text { Thalassiosira } \\
\text { pseudonana }\end{array}$ & 58 & 10.5 & 7.0 & 40.7 & 11.4 \\
& & & 3.6 & 5.94 & 0.94 \\
\hline
\end{tabular}


containing $10 \mathrm{ml}$ of prey medium at $16^{\circ} \mathrm{C}$ and were collected during exponential phase. Prey concentrations were prepared by diluting stock cultures with $0.7 \mu \mathrm{m}$ filtered, pasteurized $\left(80^{\circ} \mathrm{C}\right.$ for $\left.24 \mathrm{~h}\right)$ natural seawater and were quantified using a Model TA II Coulter Counter.
Two methods were used to establish numerical responses for the ciliates. Strobilidium neptuni and Strombidium capitatum were grown in a semi-continuous manner by a daily transfer of individual ciliates to new food. However, growing Strob. veniliae and Strom. siculum in this manner was intractable, as the
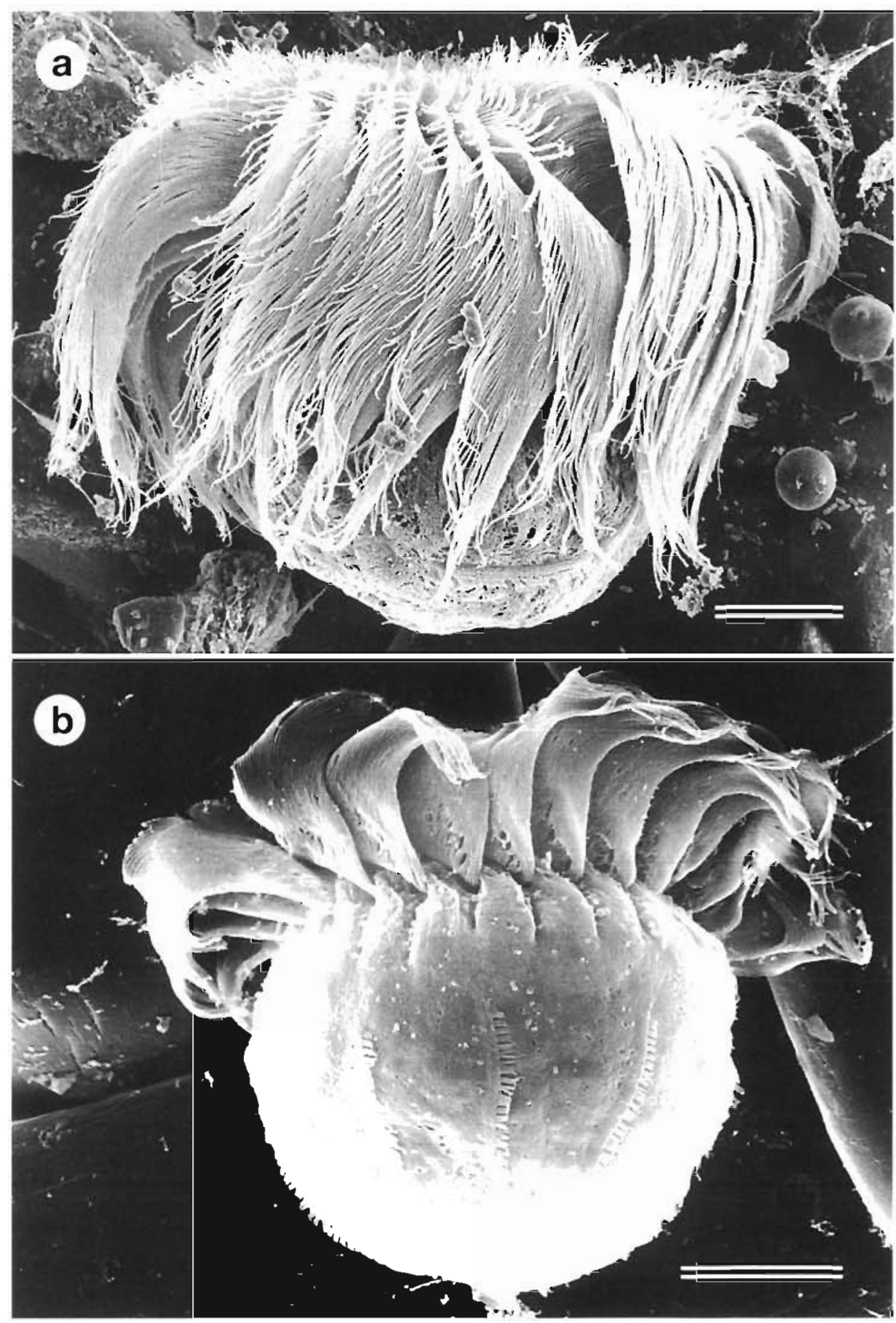

Fig. 1. Scanning electron micrographs of (a) Strobilidium neptuni and (b) Strob. veniliae. Scale bars $=10 \mu \mathrm{m}$. For further taxonomic details on these species see Montagnes \& Taylor (1994) 


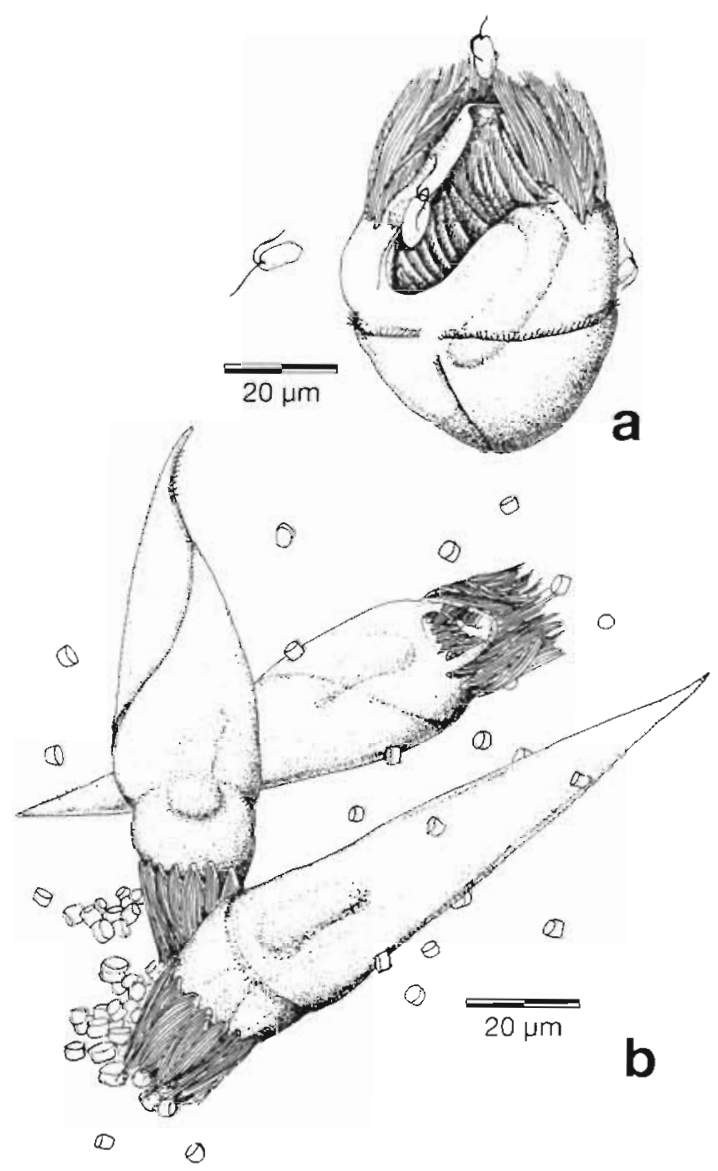

Fig. 2. Diagrams of (a) Strombidium capitatum and prey flagellates, and (b) Strom. siculum and prey diatoms. Drawn from observations of live and protargol stained cells and from scanning electron micrographs. For further taxonomic details on these 2 species see Montagnes et al. (1988b) and Montagnes \& Taylor (1994), respectively

former ciliate 'jumped' rapidly and the latter often stuck to surfaces; thus, neither was easily manipulated. Descriptions of the 2 methods follow.

Semi-continuous culture of Strobilidium neptuni and Strombidium capitatum: For any one prey concentration, ciliates were collected from stock cultures and 10 ciliates were placed in each of 3 wells in a 6 -well $\left(20 \mathrm{ml}\right.$ well $\left.{ }^{-1}\right)$ tissue plate. These wells contained $10 \mathrm{ml}$ of prey concentrations that were prepared and enumerated as described above. Ciliates were transferred using a fine drawn Pasteur pipette while observing them under a dissection microscope. Transfers were typically successful, but on the rare occasion when cells were damaged, the ciliates were replaced. Other studies have found similar transfers to cause $\sim 10$ min delays or no delays in fission rate (Adl \& Berger 1991 for Paramecium tetraurelia; Montagnes unpubl. data for Strombidinopsis multiauris). Delays in fission on the order of 10 min would cause a small $(<1 \%)$ reduction in generation time. Assuming that the delays in fission rates of the ciliates studied here would be $10 \mathrm{~min}$ or less, they were ignored in the analysis

The tissue plate with ciliates and prey was placed in the dark (to prevent ciliate mixotrophy and growth of the prey) for $24 \mathrm{~h}$ at $16^{\circ} \mathrm{C}$. After $24 \mathrm{~h}$, an equivalent prey concentration was allocated to 3 wells in a new tissue plate, and 10 randomly chosen ciliates (from the $24 \mathrm{~h}$ old well) were removed and transferred to a new well. If $>10$ ciliates were in an old well (i.e. population growth was positive), the excess were counted and removed. If $<10$ ciliates were in a well (i.e. population growth was negative), all the ciliates were transferred. It was thus possible to determine a daily change in ciliate numbers and establish a growth rate (mortality = negative growth) at a defined prey density. Growth rate was calculated as $\mu=\ln \left(\right.$ cells $_{t_{1}} /$ cells $\left._{i_{0}}\right) /\left(t_{1}-t_{0}\right)$, $t=$ time in days; i.e. exponential growth rate was assumed over the $24 \mathrm{~h}$. This semi-continuous procedure was continued for $7 \mathrm{~d}$, and the average growth rate was determined for Days 3 through 7 ; Days 1 and 2 were an acclimation period after which growth rate was relatively constant (data not shown).

For Strobilidium neptuni 32 prey concentrations were examined, ranging from 0 to $9.5 \times 10^{4}$ prey $\mathrm{ml}^{-1}$. For Strombidium capitatum 22 treatments were examined, ranging from 0 to $6 \times 10^{5}$ prey $\mathrm{ml}^{-1}$. Prey concentrations were measured before and after each transfer of the

Table 2. Relative growth rate of Strobilidium neptuni, Strob. veniliae, Strombidium capitatum, and Strom. siculum on 3 phytoflagellates. Ciliates and prey were exposed to a $14: 10 \mathrm{~h}$ light dark cycle at $16^{\circ} \mathrm{C}$ and all combinations of the 3 prey: Isochrysis galbana, Chroomonas salina and Rhodomonas lens (initial combined prey concentrations were $-3 \times 10^{4}$ cells ml ${ }^{-1}$ ). Growth rates were qualitatıve estimates of the increase in numbers: $(-)$ cells died; $(+)$ cells grew slowly; $(++)$ cells grew; $(+++)$ cells grew quickly

\begin{tabular}{|lcccc|}
\hline Prey combinations & Strob. neptuni & Strob. veniliae & Strom. capitatum & Strom. siculum \\
\hline R. Jens & - & - & - \\
I. galbana & + & + & - & - \\
C. Salina & +++ & + & - & + \\
I. galbana \& R. lens & ++ & ++ & + & + \\
I. Galbana \& C. saina & +++ & +++ & ++ & + \\
C. Salina \& R. lens & +++ & +++ & ++ & - \\
I. galbana \& C. salina \& R. lens & ++ & ++ & ++ \\
\hline
\end{tabular}


ciliates to examine the stability of the prey concentrations. For both ciliates, prey concentrations typically varied by $<10$ to $15 \%$ over the $24 \mathrm{~h}$ incubation period. Prey concentrations used for the numerical response calculations were the mean concentrations determined from the wells over Days 3 to 7.

Pre-acclimated culturing of Strobilidium veniliae and Strombidium siculum: Ciliates were collected during the exponential phase. Then 10 to 25 ciliates were transferred to tissue plate wells containing $10 \mathrm{ml}$ of prey at treatment concentrations, and acclimated in the dark at $16^{\circ} \mathrm{C}$ for $24 \mathrm{~h}$. After $24 \mathrm{~h}$, the ciliates were transferred to new prey at the same concentrations to which they were acclimated and allowed to grow. The incubation period for Strob. veniliae was $96 \mathrm{~h}$ for most treatments; however, this was too long for starving ciliates (all usually died after $<96 \mathrm{~h}$ ), and thus for concentrations below $4 \times 10^{3}$ prey $\mathrm{ml}^{-1}$, the ciliates were left for only $24 \mathrm{~h}$ after the initial $24 \mathrm{~h}$ acclimation period. For Strob. veniliae the treatments ranged from 0 to $9.2 \times 10^{4}$ cells $\mathrm{ml}^{-1}$. The incubation period for Strom. siculum was $124 \mathrm{~h}$ for the diatom experiment and $96 \mathrm{~h}$ for the 3-flagellate experiment. For Strom. siculum the treatments ranged from $10^{2}$ to $2.5 \times$ $10^{4}$ cells $\mathrm{ml}^{-1}$ for the diatom experiment and from $2.5 \times 10^{2}$ to $4.3 \times 10^{4}$ cells $\mathrm{ml}^{-1}$ for the 3 -flagellate experiment. For both ciliates, growth rates were estimated as the change in numbers over the incubation period; exponential growth was assumed over the 24 to $124 \mathrm{~h}$ incubation. As the flagellates were motile, and Thalassiosira pseudonana remains in the water column in unstirred culture flasks, it was assumed that the prey remained dispersed during the incubations. However, if settling of the diatom did occur, then the sub-maximum growth estimates for Strom. siculum (a ciliate which may be associated with surfaces, see 'Numerical response of Strom. siculum' below) may be lower than reported below.

The prey concentrations used to determine the numerical response were estimated prior to the addition of and after the removal of the ciliates. These 2 values were used to calculate the averaged concentration $(<\mathrm{C}>$, described by Frost 1972 ) over the incubation. For Strobilidium veniliae, 76 treatments were run as described above. Prey concentrations typically dropped by 5 to $35 \%$ of the initial concentration over the $96 \mathrm{~h}$, but at times the prey levels increased slightly $(\sim 15 \%)$. For Strob. siculum, 25 and 45 treatments were I un for the Thalassiosira pseudonana and 3-flagellate experiments, respectively. Prey concentrations typically decreased by 5 to $10 \%$ over the $96 \mathrm{~h}$, but at times the prey levels increased slightly $(\sim 15 \%)$.

Data analysis of growth rates: For all 4 ciliates, the numerical response data were fit to a modified Michaelis-Menten model (Eq. 1). This model was chosen since it is a good predictor of numerical responses and is based on sound theoretical mechanisms (Holling 1959, Fenchel 1986, Taniguchi \& Takeda 1988), potentially even when food is not evenly distributed (Ruxton \& Gurney 1994). Curves were fit to the data using the Marquardt-Levenberg algorithm (Sigmaplot, Jandel Scientific, CA, USA), which minimizes the sum of squares of differences between the dependent variables in the equation and the observed data. For biological data sets, this method may be more accurate and precise than methods of curve fitting that transform the model to linear forms (Berges et al. 1994).

$$
\mu=\left\{\mu_{\max } \times\left([P]-x^{\prime}\right)\right\} /\left\{k+\left([P]-x^{\prime}\right)\right\}
$$

where $\mu$ is the growth rate $\left(\mathrm{d}^{-1}\right), \mu_{\max }$ is the maximum growth rate, $[P]$ is the prey concentration (no. $\mathrm{ml}^{-1}$ ), $x^{\prime}$ is the $x$ intercept or 'threshold concentration' (the prey concentration where $\mu=0$ ), and $k$ is a constant.

\section{RESULTS AND DISCUSSION}

\section{Numerical responses of Strobilidium}

\section{Strobilidium neptuni}

Growth rates followed a rectangular hyperbolic response between 0 and $9.5 \times 10^{4}$ prey $\mathrm{ml}^{-1}$ (Fig. 3a). At concentrations $<6 \times 10^{3}$ prey $\mathrm{ml}^{-1}$ mortality occurred within the first $48 \mathrm{~h}$ (the acclimation period). After the acclimation period, Strobilidium neptuni had an observed maximum growth rate of $\mu=\sim 1.5 \mathrm{~d}^{-1}$ at saturating prey concentrations, a threshold concentration of $\sim 10^{4}$ prey $\mathrm{ml}^{-1}$ ( $320 \mathrm{ng} \mathrm{C} \mathrm{ml}^{-1}$ ), and a maximum change in growth rate between $10^{4}$ and $2 \times 10^{4}$ prey $\mathrm{ml}^{-1}$ (320 to $640 \mathrm{ng} \mathrm{C} \mathrm{ml}^{-1}$ ). Eq. (1) was fit to points from 0 to $9.5 \times 10^{4}$ prey $\mathrm{ml}^{-1}$ (Fig. 3a, Table 3).

This is the first description of growth parameters for Strobilidium neptuni. Although this species is morphologically similar to Strob. spiralis, its numerical response is unique (see Table 4). The most striking aspect of the numerical response is the atypically high threshold concentration (see 'Mortality rates, growth rates, and threshold concentrations' below), but the maximum growth rate is also atypically high for a species of this size (see Table 4). These 2 aspects of the numerical response make this species unique.

\section{Strobilidium veniliae}

Growth rate followed a rectangular hyperbolic response between $1.0 \times 10^{3}$ and $5.7 \times 10^{4}$ prey $\mathrm{ml}^{-1}$ (Fig. 3b). Strobilidium veniliae had an observed maximum growth rate of $\mu=\sim 0.7 \mathrm{~d}^{-1}$ at saturating prey con- 

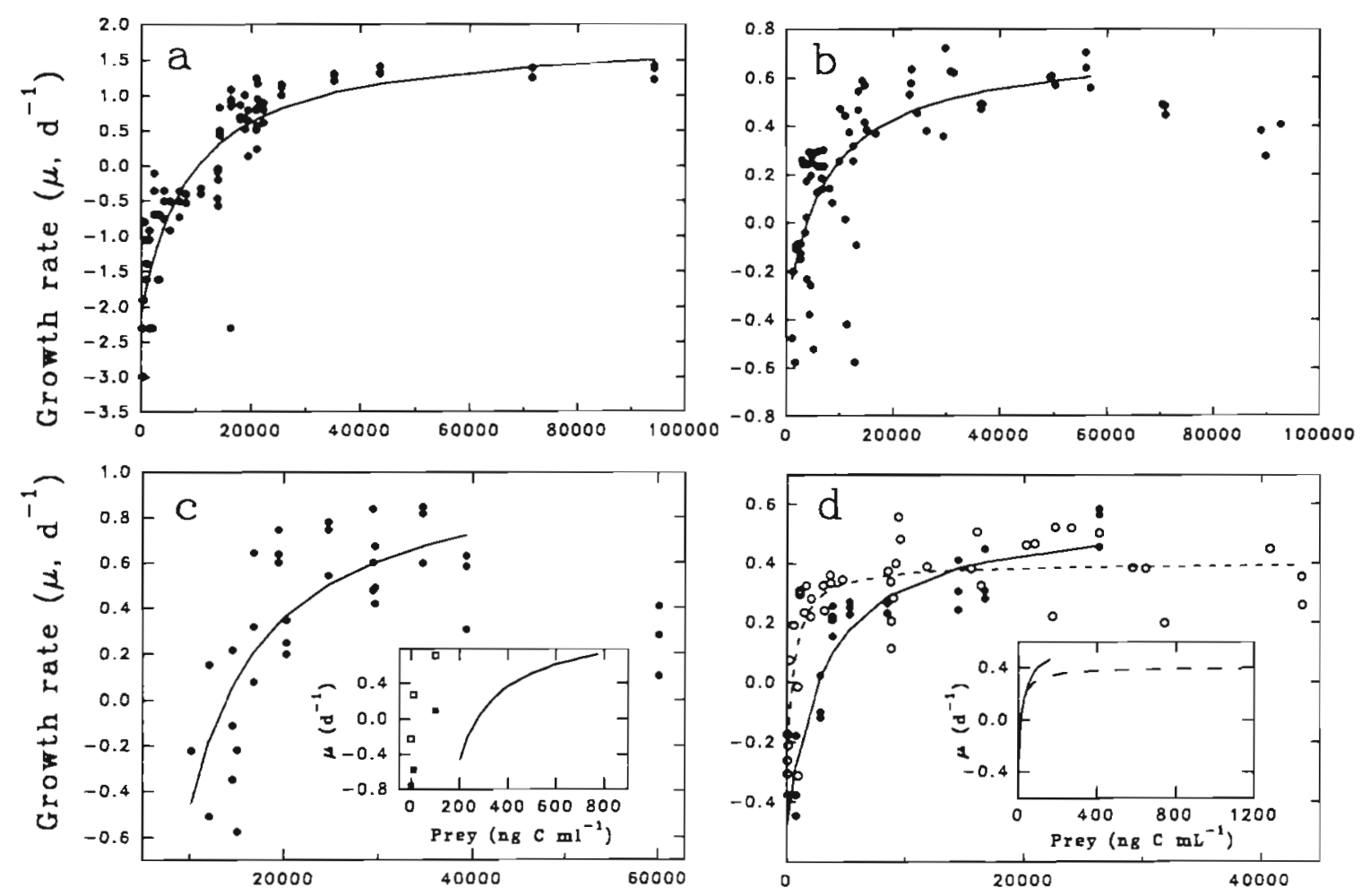

Prey concentration (\# $\mathrm{mL}^{-1}$ )

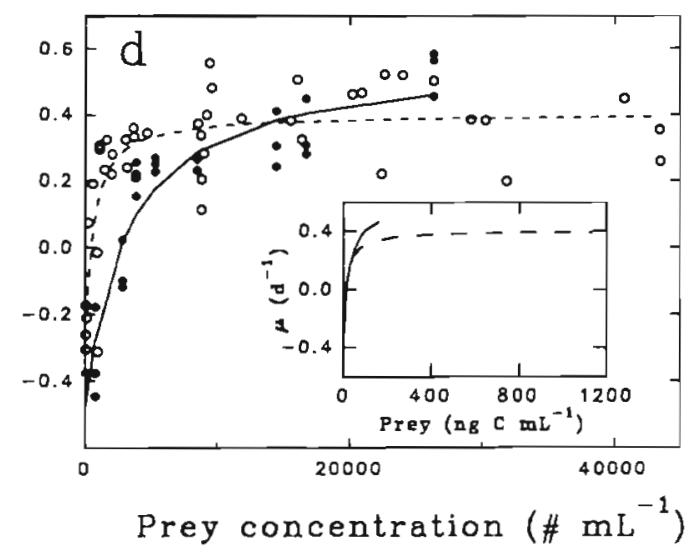

Fig. 3. Numerical responses of 4 oligotrich ciliates: growth rate $\left(\mu, \mathrm{d}^{-1}\right)$ vs food concentration (prey cells ml $\left.{ }^{-1}\right)$. (a) Strobilidium neptuni; (b) Strob. veniliae; (c) Strombidium capitatum, and (d) Strom. siculum. Circles represent observed growth rates, and lines represent the modified Michaelıs-Menten fit to the data (Eq. 1). See Table 3 for parameters and estimates of error associated with these curves. In the inset of (c), same as above except that prey concentrations have been converted to carbon, using values presented in Table 1; squares in the inset represent growth rates determined for Strom. capitatum grown at 3 food concentrations in the dark (solid squares) and in the light (open squares) (from Tables 5 and 6. Stoecker et al. 1988/1989, but see text for details). In (d), the 2 types of lines and circles represent 2 different foods: the diatom (solid line, solid circles) and the 3 flagellates (broken line, open circles). In the inset of (d), same as above except that prey concentrations were converted to carbon, using values presented in Table 1

centrations, a threshold concentration of $3.8 \times 10^{3}$ prey $\mathrm{ml}^{-1}$ ( $75 \mathrm{ng} \mathrm{C} \mathrm{ml}^{-1}$ ), and a maximum change in growth rate between $3.8 \times 10^{3}$ and $1.5 \times 10^{4}$ prey $\mathrm{ml}^{-1}$ ( 75 to $300 \mathrm{ng} \mathrm{C} \mathrm{ml}^{-1}$ ). At concentrations above $\sim 5.7 \times 10^{4}$ prey $\mathrm{ml}^{-1}$ growth was inhibited, and these data were not used to estimate the numerical response; a similar inhibition has been observed for other planktonic ciliates (Verity 1985, Montagnes 1993, and this study; see 'Strombidium capitatum', below). Eq. (1) was fit to points between $1.0 \times 10^{3}$ and $5.7 \times 10^{4}$ prey $\mathrm{ml}^{-1}$ (Fig. 3 b, Table 3 )

This is the first description of growth parameters for Strobilidium veniliae, but this species is similar in size to Strob. cf. spiralis, studied by Verity (1991). Although grown at different temperatures, on different prey, and in different culture vessels, these 2 species have similar threshold concentrations and similar regions of maximum change in growth rate (Table 4). However, the maximum growth rates of the 2 species differ and may be due to the different temperatures at which they were grown (see 'Variation among species' below).
Comparison of the 2 species

In gross morphology, the 2 Strobilidium species appear similar to a number of species whose ecology has been studied (Rassoulzadegan 1982, Smetacek 1984, Jonsson 1986, Sheldon et al. 1986, Stoecker \& Michaels 1991, Verity 1991). In food web analysis, biologists often lump these ciliate types into groups: e.g. 'oligotrichs', 'Strobilidium', or, erroneously, 'Lohmanniella'. However, the 2 Strobilidium species examined in this study differ in their numerical responses (see Fig. 4). Assuming that the food provided elicited maximal responses and ciliates exploited small patches of prey, these data suggest Strob. neptuni and Strob, veniliae would behave differently: Strob. neptuni would thrive in presumably rare patches of very high prey abundance, while Strob. veniliae would exploit patches of lower prey abundance. Ignoring these species differences by considering all Strobilidium species to be the same could inaccurately represent their impact in planktonic systems. 
Table 3. Growth parameters and estimates of error of the numerical response curves (modified Michaelis-Menten fit, Eq. 1) for Strobilidium neptuni, Strob, veniliae, Strombidium capitatum, and Strom. siculum, presented in Figs. 3a-d \& 4 . $\mu_{\mathrm{max}}$ : the maximum growth rate of the ciliate $\left(\mathrm{d}^{-1}\right) ; k$ : a constant (prey number $\mathrm{ml}^{-1}$ ); $x^{\prime}$ : the threshold concentration (prey number $\mathrm{ml}^{-1}$ ). Values of $k$ and $x^{\prime}$ in parentheses are prey concentrations in terms of carbon, calculated from values given in Table 1 (ng C ml-1) and used to fit curves in Fig. 4. Number of data points (n) used to fit the lines are reported for each fit

\begin{tabular}{|c|c|c|c|}
\hline & Value & $\begin{array}{l}\text { Standard } \\
\text { error }\end{array}$ & $\begin{array}{l}\text { Coefficient } \\
\text { of variation }\end{array}$ \\
\hline \multicolumn{4}{|c|}{$\begin{array}{l}\text { Strob. neptuni, parameters for lines depicted in Figs. 3a } \\
\& 4(n=96)\end{array}$} \\
\hline$\mu_{\max }$ & 1.845 & 0.257 & 14 \\
\hline$k$ & $19070(610)$ & 2866 & 15 \\
\hline$x^{\prime}$ & $10230(327)$ & 920 & 9 \\
\hline \multicolumn{4}{|c|}{$\begin{array}{l}\text { Strob. veniliae, parameters for lines depicted in Figs. } 3 b \\
\& 4(n=76)\end{array}$} \\
\hline$\mu_{\max }$ & 0.735 & 0.126 & 17 \\
\hline$k$ & $11470(224)$ & 4412 & 39 \\
\hline$x^{\prime}$ & $3824(75)$ & 59 & 16 \\
\hline \multicolumn{4}{|c|}{$\begin{array}{l}\text { Strom. capitatum, parameters for lines depicted in Figs. } 30 \\
\& 4(n=36)\end{array}$} \\
\hline$\mu_{\max }$ & 1.07 & 0.98 & 93 \\
\hline$k$ & $12400(242)$ & 6410 & 52 \\
\hline$x^{\prime}$ & $13900(271)$ & 899 & 7 \\
\hline \multicolumn{4}{|c|}{$\begin{array}{l}\text { Strom. siculum, parameters for solid line (prey }=\text { Thalas- } \\
\text { siosira pseudonana) depicted in Fig. } 3 \mathrm{~d}(\mathrm{n}=25)\end{array}$} \\
\hline$\mu_{\max }$ & 0.573 & 0.067 & 12 \\
\hline & $5851(35)$ & 1236 & 21 \\
\hline$x^{\prime}$ & $2703(16)$ & 338 & 13 \\
\hline \multicolumn{4}{|c|}{$\begin{array}{l}\text { Strom. siculum, parameters for broken line (prey = } \\
3 \text { flagellates) depicted in Fig. } 3 d \text { and for the line depicted } \\
\text { in Fig. } 4(n=45)\end{array}$} \\
\hline$\mu_{\max }$ & 0.400 & 0.030 & 8 \\
\hline & $960(26)$ & 326 & 34 \\
\hline$x^{\prime}$ & $430(11)$ & 104 & 24 \\
\hline
\end{tabular}

\section{Numerical responses of Strombidium}

\section{Strombidium capitatum}

Growth rates followed a rectangular hyperbolic response between $1 \times 10^{4}$ and $4 \times 10^{4}$ prey $\mathrm{ml}^{-1}$ (Fig. 3c). Strom. capitatum had an observed maximum growth rate of $\mu=\sim 0.7 \mathrm{~d}^{-1}$ at saturating prey concentrations, a threshold concentration of $1.4 \times 10^{4}$ prey ml $^{-1}(270 \mathrm{ng} \mathrm{C}$ $\mathrm{ml}^{-1}$, and a maximum change in growth rate between $1.4 \times 10^{4}$ and $2.5 \times 10^{4}$ prey $\mathrm{mI}^{-1}$ (270 and $490 \mathrm{ng} \mathrm{C}$ $\mathrm{ml}^{-1}$ ). There was also a decrease in growth rate with food concentration above $4 \times 10^{4}$ prey $\mathrm{ml}^{-1}(780 \mathrm{ng} \mathrm{C}$ $\left.\mathrm{ml}^{-1}\right)$. At 4 concentrations below $10^{4}$ prey $\mathrm{ml}^{-1}(0,5 \times$ $10^{2}, 10^{3}$, and $5 \times 10^{3}$ ) and at 2 above $6 \times 10^{4}$ prey $\mathrm{ml}^{-1}$ $\left(8 \times 10^{4}\right.$ and $\left.10^{5}\right)$ mortality occurred within the $48 \mathrm{~h}$ acclimation period; these data are not presented in Fig. 3c. Eq. (1) was fit to points from $10^{4}$ to $6 \times 10^{4}$ prey $\mathrm{ml}^{-1}$ (Fig. 3c, Table 3).
Strombidium capitatum is typically mixotrophic (Stoecker et al. 1987, 1988/1989, Laval-Peuto \& Rassoulzadegan 1988, Stoecker \& Silver 1990, Stoecker \& Michaels 1991). However, since growth rate estimates made over extended periods in the dark can be positive (Fig. 3c), it is not an obligate mixotroph. This observation seems to contradict the findings of Stoecker \& Silver (1990) who suggested that Strom. capitatum requires chloroplasts for continued growth. However, in the present study the ciliate was constantly provided with new autotrophic prey, which was grown in the light. Thus, Strom. capitatum may not be an obligate mixotroph but may require chloroplasts in its diet. Possibly, the ciliates would have survived at lower prey concentration if they were grown in the light.

Strombidium capitatum shows morphological variation between clones (Montagnes et al. 1988b) but appears to be a cosmopolitan species, occurring in the northwestern and northeastern Atlantic (Leegaard 1915, Stoecker et al. 1987), the northeastern Pacific (Martin \& Montagnes 1993, this study), and the Mediterranean (Laval-Peuto \& Rassoulzadegan 1988). Hence, the numerical response data (Fig. 3c) may be useful to represent growth (in the dark) of this common, large mixotrophic ciliate. Observations for Strom. capitatum isolated from British Columbian waters, however, differ from the only other growth estimates determined for Strom. capitatum (Stoecker et al. 1988/1989), even though the British Columbian cultures and Stoecker et al.'s cultures were grown under similar conditions (i.e. the same prey species, similar temperature, and salinity, but slightly different media and culture vessels). Stoecker et al. (1988/1989) reported changes in cell numbers and volume of Strom. capitatum in the dark and light over $48 \mathrm{~h}$, and they showed that in the light Strom. capitatum survives longer when starving and grows faster when fed. Using the data of Stoecker et al. (Tables 5 and 6 , $1988 / 1989$ ) it was possible to determine growth rates (squares in the inset of Fig. 3c) and show that these rates differ from those determined for the British Columbian isolate (solid line in the inset of Fig. 3c).

Why do the results of these 2 studies differ? In the present study, Strombidium capitatum was acclimated to food concentrations for $48 \mathrm{~h}$, and then maintained at these concentrations for up to $5 \mathrm{~d}$. Therefore, the mortality estimates made in this study would likely be higher at low food concentrations than those determined for ciliates maintained for only $48 \mathrm{~h}$. Furthermore, it may be that Stoecker et al.'s positive growth rates would not have been sustained for several days. Alternatively, a number of other factors may have affected growth (e.g. differences in food quality, differences between clones of the same species, differences 
Table 4. Growth parameters of several species in the genera Strobilidium and Strombidium. TC: threshold concentration, where net growth is zero; RMGI (region of maximum growth increase): range of food concentrations where growth rate increases from zero to near its maximum; Temp.: temperature at which ciliates were grown; Volume: live cell volume of the species of Strobilidium or Strombidium; Obs. $\mu_{\max }$ : observed maximum growth rate of the Strobilidum and Strombidium species; \#1, \#2, and \#3 Pr. $\mu_{\mathrm{max}}$ : predicted maximum growth rates from Eqs. (2), (3) \& (4), respectively; -: no data available for this parameter

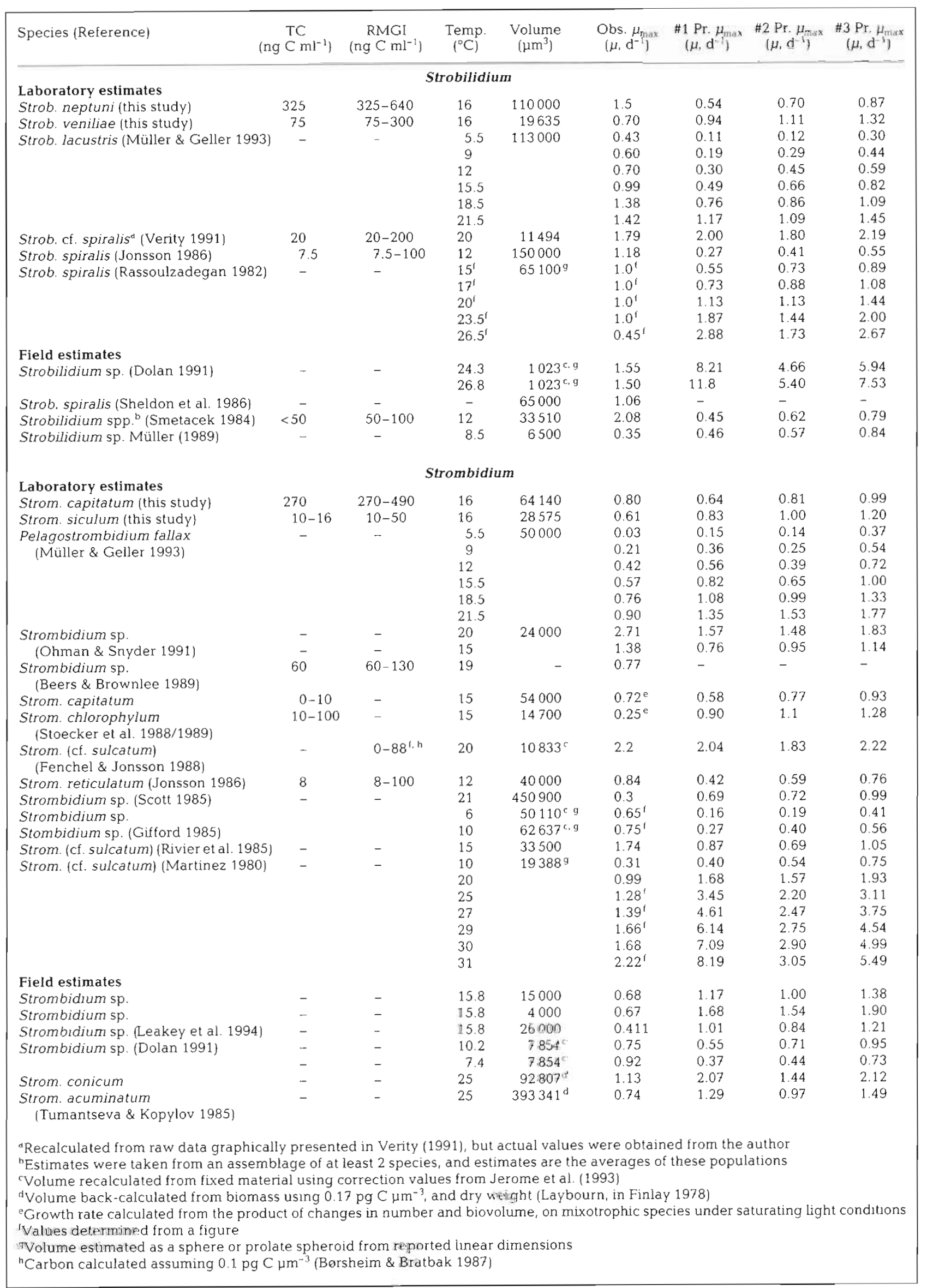




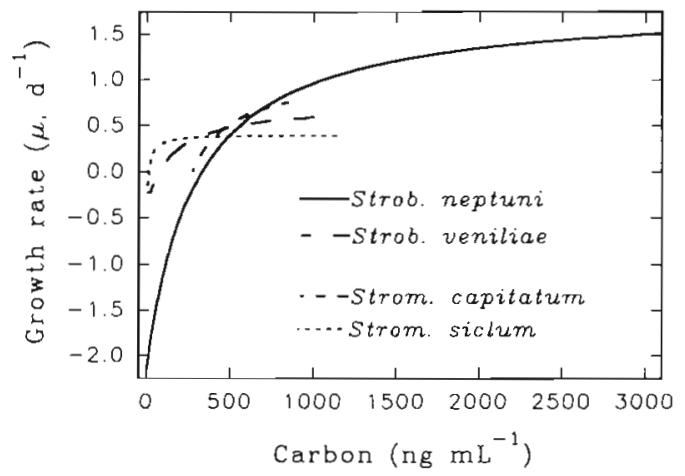

Fig. 4. Numerical responses of Strobilidium neptuni, Strob. veniliae, Strombidium capitatum, and Strom. siculum: growth rate $\left(\mu, \mathrm{d}^{-1}\right)$ vs food concentration (prey carbon $\mathrm{ml}^{-1}$ ). Lines represent the modified Michaelis-Menten fit (Eq. 1) to the data presented in Fig. 3a-d. See Table 3 for parameters associated with these curves

in culturing techniques, or ageing of cultures). Further investigations are required on the growth and mortality rates of this common but morphologically variable species; it may even be that like 'Strobilidium spiralis', 'Strombidium capitatum' is composed of several species.

\section{Strombidium siculum}

When fed Thalassiosira pseudonana, the growth rates of Strombidium siculum followed a rectangular hyperbolic response between $10^{2}$ and $2.5 \times 10^{4}$ prey $\mathrm{ml}^{-1}$ (0.6 to $150 \mathrm{ng} \mathrm{C} \mathrm{ml}^{-1}$ ), and mortality occurred at concentrations below $2.7 \times 10^{3}$ prey ml ${ }^{-1}\left(16 \mathrm{ng} \mathrm{C} \mathrm{ml}^{-1}\right)$ (Fig. 3d, solid circles). When fed the 1:1:1 combination of the flagellates Isochrysis galbana, Chroomonas salina, and Rhodomonas lens, the growth rate followed a rectangular hyperbolic response between $2.5 \times 10^{2}$ and $4.3 \times 10^{4}$ prey ml-1 $\left(6.5\right.$ to $\left.1100 \mathrm{ng} \mathrm{C} \mathrm{ml}^{-1}\right)$, and mortality occurred at concentrations below $4.3 \times 10^{2}$ prey $\mathrm{ml}^{-1}$ (11 ng C ml-1) (Fig. 3d, open circles). For each of the 2 experiments, Eq. (1) was fit to all the data (Fig. 3d, solid line for $T$. pseudonana, broken line for the 3 flagellates; Table 3 ).

Strombidium siculum had an observed maximum growth rate of $\mu \leq 0.6 \mathrm{~d}^{-1}$ at saturating prey concentrations, a threshold concentration of 10 to $16 \mathrm{ng} \mathrm{C} \mathrm{ml}^{-1}$, and a maximum change in growth response between 10 and $50 \mathrm{ng} \mathrm{C} \mathrm{ml}^{-1}$. When viewed in terms of carbon per volume (inset, Fig. $3 d$ ), the 2 prey types produced responses that were not significantly different $(\alpha=$ $0.05 \mathrm{j}$, based on the parameters of the 2 curves and their associated estimates of error (Table 3 ).

This work is the first study of the growth responses of an elongate, surface-associated Strombidium species (i.e. it was isolated from the plankton but was often found to graze along surfaces in cultures). This elongate morph of Strombidium seems to be a common but poorly examined type (Leegaard 1915, Wailes 1929, Corliss \& Snyder 1986, Montagnes \& Taylor 1994). There have been other studies on what are likely surface-associated species of Strombidium (e.g Martinez 1980, Rivier et al. 1985, Fenchel \& Jonsson 1988, Bernard \& Rassoulzadegan 1990, Ohman \& Snyder 1991), but these were truncated forms (often referred to as Strom. sulcatum, but see Montagnes et al. 1990). The elongate shape of Strom. siculum may be related to its feeding and swimming behavior, as this species differed from others (unpubl. obs.). In cultures not transferred for weeks, Thalassiosira pseudonana began to form 'clumps' and the ciliate was observed to move around these aggregates (e.g. Fig. 2b). This behavior suggests the ciliate may graze preferentially on diatom aggregates that form in the plankton (e.g. Riebesell 1991). Since surface-associated ciliates may be important links in the formation and mineralization of sinking detritus (Silver et al. 1984, Lochte 1991), further investigations of species with this behavior seems warranted.

\section{A synthesis of oligotrich growth rates}

Variation among species

A striking feature of the numerical response curves of the 4 species presented here is that they differ, even when the prey abundances are converted to carbon units (Fig. 4). Surprisingly, the largest species (Strobilidium neptuni) exhibited the highest growth rate. This is counter intuitive, as smaller cells are expected to grow faster (e.g. Fenchel 1974). Montagnes et al. (1988a), Müller \& Geller (1993), and Nielsen \& Kiørboe (1994; note the erratum, Limnol. Oceanogr. 39: 1423) have provided multiple regressions using ambient temperature and cell volume to predict ciliate growth rates (Eqs. 2, $3 \& 4$, respectively; see below). The predicted growth rates (calculated from Eqs. 2,3 \& 4) for the 4 species presented here (at saturating food concentrations and $16^{\circ} \mathrm{C}$ ) indicate considerable differences between the predicted and observed responses (Table 4). Thus, although such multiple regressions may be useful to estimate ciliate assemblage growth rates, it would be inappropriate to apply them to single species with any confidence. This point is further supported by the difference between observed and predicted growth rates of a number of other species of Strobilidium and Strombidium (Table 4).

Eqs. (2) to (4):

$\ln \mu_{\max }=0.1438 T-0.3285 \ln \left(V \times 10^{3}\right)-1.3815$ 
$\ln \mu_{\max }=1.52 \ln T-0.27 \ln \mathrm{V}-1.44$

(Müller \& Geller 1993)

$\ln \mu=0.095 T-0.243 \ln V+1.1569$

(Nielsen \& Kiørboe 1994)

where $\mu_{\max }$ is the maximum growth rate, $\mathrm{d}^{-1} ; \mu$ is the observed growth rate, $\mathrm{d}^{-1} ; T$ is temperature, ${ }^{\circ} \mathrm{C}_{i}$ and $V$ is ciliate cell volume, $\mu^{3}$.

Eqs. (2) \& (3) were determined using a number of ciliate genera, only a few of which were oligotrichs, and Eq. (4) was based on field samples composed of planktonic oligotrichs. When Montagnes et al. (1988a) presented Eq. 2, they indicated that a comparison of observed growth rates of planktonic oligotrichs (i.e. data from the literature or personal communications) differed on average by $<2 \%$ from their predicted estimates. Since that publication, a number of other growth rates for species of Strobilidium and Strombidium of known cell volumes at specified temperatures have become available (Table 4 ). These data can be used to assess the predictive quality of Eqs. (2), (3) \& (4).

If a formula is predictive, the observed vs predicted values should be normally distributed around a line with a slope of 1 (i.e. the thick lines in Fig. $5 a-c$ ), the regression line through the data (i.e. the thin lines in Fig. $5 a-c)$ should fall on the $1: 1$ line, and the $R^{2}$ value should be near unity (i.e. the difference between observed and predicted growth rates should be normally distributed around zero; see Fig. 5d-f). Using these criteria, the predictive quality of Eqs. (2), (3) \& (4) can be compared (Fig. 5). Note that only laboratory derived data (Table $4, \mathrm{n}=40$ ) were used in the following analysis, as uncontrolled factors (e.g. food concentration) may have affected field estimates.

Eq. (3) (Müller \& Geller 1993) appears to be the best predictor of growth rate for species of Strobilidium and Strombidium, while Eq. (2) (Montagnes et al. 1988a) and Eq. (4) (Nielsen \& Kiørboe 1994) are less predictive (Fig. 5). The values of 'observed - predicted' growth rate (Fig. $5 \mathrm{~d}-\mathrm{f}$ ) are normally distributed for Eq. (3) and are not normally distributed for Eq. (2) or (4) (Kolmogorov-Smirnov test of normality, $\alpha=0.05$ ): furthermore, the mean value for these data obtained from Eq. (3) is not significantly different from the expected value of zero $(\alpha=0.05)$. For all 3 equations, the main source of over-prediction of growth rate is related to temperatures $>20^{\circ} \mathrm{C}$ (Table 4 ); these poor predictions are undoubtedly partially due to the lack of data at this high end. Eq. (3) (Müller \& Geller 1993) treats growth rate as a power function of temperature (i.e. $T^{x}$ ), while Eqs. (2) and (4) consider growth rate to increase exponentially with temperature (i.e. $\mathrm{e}^{T}$ ). The result of these differences is that Eq. (3) is a more conservative, and apparently a more realistic, predictor of growth rate at
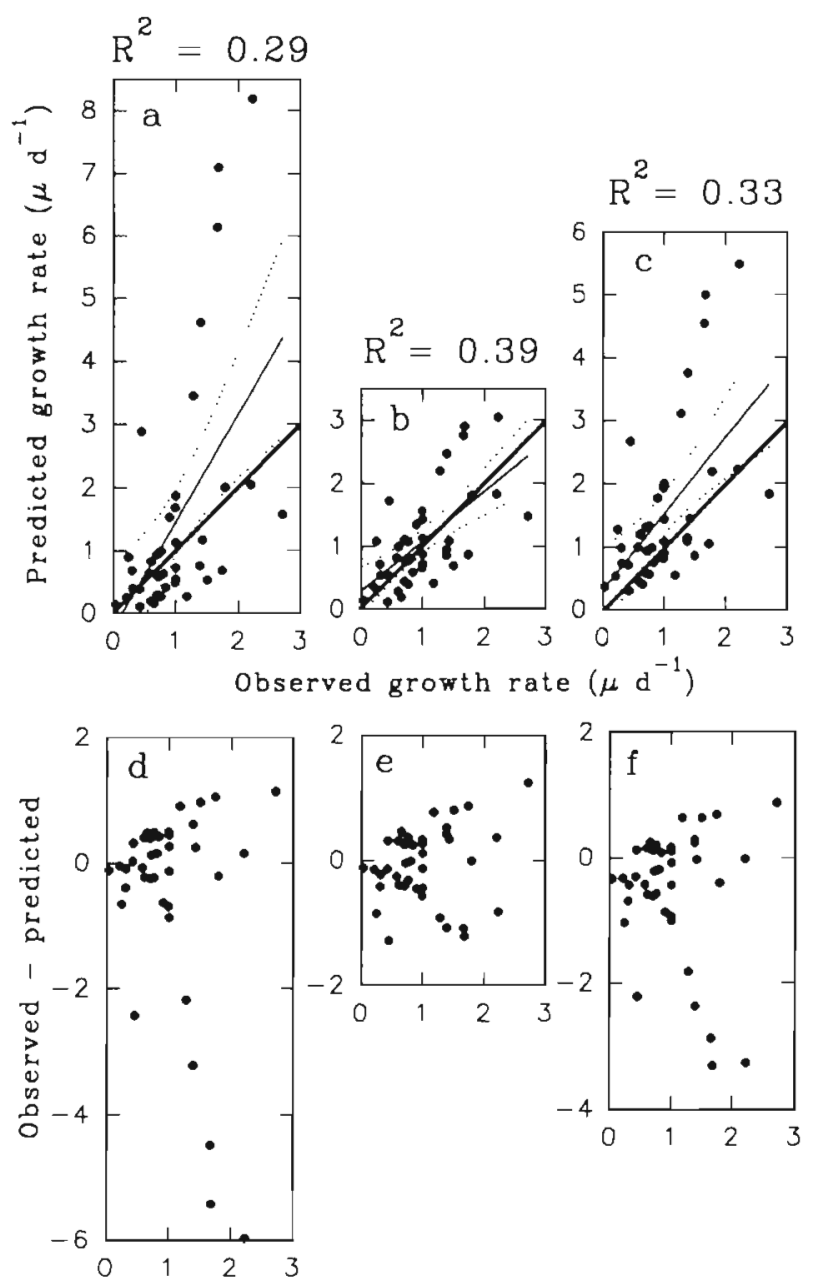

Fig. 5. Comparison of the predictive quality of 3 formulae that determine ciliate growth rate from measurements of ciliate cell volume and ambient temperature (Eqs. 2, 3 \& 4, in text). Laboratory derived data presented in the last 4 columns of Table 4 were used in this analysis. Observed growth rate is the maximum observed growth rate for a ciliate species of a specific volume which was maintained at a known temperature. Predicted growth rate is the rate that was calculated for this ciliate using Eq. (2), (3) or (4). For all panels, $n=40$. (a-c): Comparisons of the observed and predicted growth rates for Eq. (2) (Montagnes et al. 1988a), Eq. (3) (Müller \& Geller 1993), and Eq. (4) (Nielsen \& Kiørboe 1994), respectively. Thick solid lines are 1:1 ratio, where points would ideally fall; thin solid lines are regressions through the data (solid circles); and broken lines are $95 \%$ confidence intervals around the regressions. $R^{2}$ values above $(a)-(c)$ relate to the fit of the data to thin solid Iines. (d-e) Difference between observed and predicted growth rates vs observed growth rate, for Eqs. (2), (3) \& (4), respectively

temperatures $>20^{\circ} \mathrm{C}$. Rather than use the data presented in Table 4 to establish another multiple regression, it seems more prudent at this time to use Eq. (3) (Müller \& Geller 1993) to predict in situ maximum growth rates of field populations of the genera Strobilidium and Strombidium. 
Mortality rates, growth rates, and threshold concentrations

A common feature of the 4 ciliates in this study was their rapid mortality rates at sub-threshold concentrations: virtually all the ciliates died after 1 to $2 \mathrm{~d}$, at subthreshold concentrations. The only comparable mortality data for species of Strobilidium and Strombidium also indicate a similar phenomenon: Wickham et al. (1993) observed that 50 cells of the freshwater species Strob. gyrans all died in slightly over a day when removed from their food, and Fenchel \& Jonsson (1988) observed $90 \%$ mortality of Strom. cf. sulcatum after $3.5 \mathrm{~d}$ of starvation. In contrast, other types of ciliates survive 5 to $7 \mathrm{~d}$ after being starved (Jackson \& Berger 1984, 1985, T. Nielsen pers comm.). These rapid death rates of Strobilidium and Strombidium are of consequence to our understanding of ciliates dynamics in food webs. Planktonic ciliate populations, at their maximum growth and grazing rates, are potentially capable of depleting their prey populations (Banse 1982, Montagnes 1993). If this occurs, the above data suggest that after exhausting their food, oligotrichs would die due to starvation within 1 to $3 \mathrm{~d}$. Many of the ciliates would therefore not be available to mesozooplankton predators if the predators had growth and grazing response times of greater than $3 \mathrm{~d}$. Thus, if ciliates 'bloom' on small scales as a result of encountering abundant prey populations (e.g. Andersen \& Sørensen 1986), they may subsequently be a sink rather than a link to upper trophic levels. An alternate possibility is that ciliates exist in small $(<1 \mathrm{~m}$, vertical scale) patches in the plankton, and their dispersal times between patches are on the order of hours (see Tiselius et al. 1993), and therefore they do not starve and die. Both of these arguments ignore the possibility of resting stages. Although resting cysts are formed by some oligotrichs (Reid 1987, Jonsson 1994) and cysts collected from sediments (depth $>20 \mathrm{~m}$ ) produce oligotrichs in the laboratory (Kim \& Taniguchi 1995), there have been no observations of cyst formation in cultured naked oligotrichs. Whether or not species of Strobilidium and Strombidium form cysts in nature to avoid starvation has yet to be well established; the field data presented by Reid (1987) and lab data by Kim \& Taniguchi (1995) are the only evidence for encystment of naked planktonic oligotrichs

Although Strobilidium (often called Lohmanniella) and Strombidium (sometimes called Laboea in older literature) are regularly reported in field samples from marine plankton, there have only been a few controlled growth studies on these genera (Table 4). In general, these oligotrichs have maximum growth rates $\left(\mu, \mathrm{d}^{-1}\right)$ ranging from $\sim 0.3$ to 2.2 (at temperatures ranging from 6 to $31^{\circ} \mathrm{C}$ ). With the exception of Strob. neptuni and Strom. capitatum, they have similar threshold concentrations (10 to $100 \mathrm{ng} \mathrm{C} \mathrm{ml}^{-1}$ ) and regions of maximum increase in growth rate $(20$ to $300 \mathrm{ng} \mathrm{C} \mathrm{ml} \mathrm{C}^{-1}$ ). Strob. neptuni and Strom. capitatum, however, seem atypical in their responses (Table 4); these species exhibited unusually high threshold concentrations and only grew rapidly at extremely high food concentrations

There are several reasons why the threshold concentrations may have been high for Strobilidium neptuni and Strombidium capitatum. For instance, culturing conditions such as prey quality may not have been ideal for their growth, and the semi-continuous transferring technique could have inhibited growth. However, such biases have to some extent been accounted for (see above). It is also possible that the responses observed for Strob. neptuni and Strom. capitatum were real. Generally, growth rate experiments on oligotrichs have been determined over 24 to $48 \mathrm{~h}$ periods, sometimes without an acclimation period. During the first $48 \mathrm{~h}$ at sub-threshold concentrations, oligotrichs tend to decrease in size both by division (without growth) and by cell shrinkage (Fenchel \& Jonsson 1988, Stoecker et al. 1988/1989, Montagnes unpubl. data). Once cells have decreased to their minimum size they then die, due to starvation le.g. Fenchel \& Jonsson (1988) observed an initial decrease in cell size of Strom. cf. sulcatum after $50 \mathrm{~h}$ post-starvation and then a high mortality rate over the next $35 \mathrm{~h}$ ]. As the growth estimates in this work were made over several days with an acclimation period, they should provide higher and more realistic measurements of growth and mortality at a single, semi-continuous prey concentration. This, coupled with the fact that Strob. neptuni and Strom. capitatum are large and may require considerable amounts of food to survive, suggests that the growth, mortality, and threshold values determined for these species are real.

\section{An ecological implication of the numerical responses}

From field data and physical modeling predictions, there are strong indications that phytoplankton abundance varies by several fold over small vertical scales (<1 m) (Derenbach et al. 1979, Owen 1989. Cowles et al. 1993, Franks 1995), but assessing the occurrence and duration of these patches is often intractable. It is possible that the numerical response of ciliates can be used to support the suggested existence of small-scale patches. Studies indicate that: (1) oligotrichs similar to those presented in Table 4 are almost always present at average concentrations of 1 to 10 cells $\mathrm{ml}^{-1}$ (Fenchel 1987, Lynn \& Montagnes 1991), therefore ciliates must be surviving in situ; (2) estimates of prey biomass ( 2 to 
$20 \mu \mathrm{m}$ in diameter) in coastal waters, where ciliates have been examined, often range between 5 and $50 \mathrm{ng}$ $\mathrm{C} \mathrm{ml}^{-1}$ (e.g. Smetacek 1981, for Kiel Bight; Andersen \& Sørensen 1986, for Danish waters; Rassoulzadegan et al. 1988, for the NW Mediterranean Sea; Haigh \& Taylor 1991, Haigh et al. 1992, Montagnes 1993, for NE Pacific waters); (3) oligotrich maximum growth rates occur at concentrations $>100 \mathrm{ng} \mathrm{C} \mathrm{m}^{-1}$ (Table 4), which are above typical prey biomass levels; (4) ciliate threshold concentrations range around 10 to $100 \mathrm{ng} \mathrm{C}$ $\mathrm{ml}^{-1}$ (Table 4), which are also near or above typical prey biomass levels; and (5) ciliates die over a period of hours to days when food levels are depleted below threshold concentrations. These data suggest that since ciliates are present in the plankton, they must encounter prey concentrations of $>10 \mathrm{ng} \mathrm{C} \mathrm{ml}^{-1}$ to survive. Furthermore, many planktonic ciliates increase their growth rates when exposed to high food levels (>100 $\mathrm{ng} \mathrm{C} \mathrm{ml} \mathrm{m}^{-1}$ ) which suggests that they encounter such levels. Finally, ciliates die over a short period when they are starved (hours to days), suggesting that ciliates rarely experience long periods of starvation. If typical levels of 2 to $20 \mu \mathrm{m}$ prey, measured over several meters, range between 5 and $50 \mathrm{ng} \mathrm{C} \mathrm{ml}{ }^{-1}$, then one way that ciliates could obtain their maximum growth rates is if the prey are distributed into small concentrated patches. This argument fits well with the smallscale patch scenario suggested by several authors (e.g. Owen 1989, Davis et al. 1991, Cowles et al. 1993, Franks 1995).

The distribution, size, frequency, and persistence of these small-scale patches, which may be on the order of $<1 \mathrm{~m}$ thick and many meters wide, will obviously affect the way in which ciliates exploit them. In a model, Tiselius et al. (1993) examined the effect of small-scale patches on ciliate growth, grazing and motility, and speculated that fast growing phytoflagellates may create thin layers ( $<1 \mathrm{~m}$ thick), and ciliates may be able to exploit these conditions. It is not known if ciliates encounter patches, fully exploit them and then move on; if ciliates constantly move between small patches; if ciliates are passively aggregated with their prey by physical processes; or if a combination of these conditions occurs (e.g. Stoecker et al. 1984). There is a need to make measurements at the scale of these patches to assess if our 'average' measurements of the water column are missing important dynamics within small-scale patches.

Acknowledgements. I thank M. Watt, T Sutherland, and $\mathrm{R}$. Haigh for their help in the collection of samples and E. Simons and $J$. Ramirez for their help with phytoplankton cultures. I thank E. J. Lessard for her support while this manuscript was being prepared. I. also thank P. Jonsson, P. Verity, T Weisse, $P$. Boyd, and 3 anonymous reviewers for their comments at various stages in the development of this manuscript. Thus work was partially funded by Natuial Science and Engineering Research Council (NSERC) graduate and postdoctoral fellowships awarded to D.J.S.M and NSERC operating grants A6137 and 5-80128 awarded to F. J. R. Taylor and P. J. Harrison, respectively.

\section{LITERATURE CITED}

Adl SM, Berger JD (1991) Timing of oral morphogenesis and its relation to commitment to division in Paramecium tetraurelia. Exp Cell Res 192:497-504

Andersen P, Sorensen HN. (1986) Population dynamics and trophic coupling in pelagic microorganisms in eutrophic coastal waters. Mar Ecol Prog Ser 33:99-109

Banse K (1982) Cell volume, maximal growth rates of unicellular algae and ciliates, and the role of ciliates in the marine pelagial. Limnol Oceanogr 27:1059-1071

Beers JR, Brownlee DC (1989) Laboratory observations on the reproduction and feeding of a pelagic strombidid ciliate. IMR Reference Report 88-4, Univ. of California, San Diego

Berges JA, Montagnes DJS, Hurd CL, Harrison PJ (1994) Fitting ecological and physiological data to rectangular hyperbolae: a comparison of methods using Monte Carlo simulations. Mar Ecol Prog Ser 114:175-183

Bernard C, Rassoulzadegan F (1990) Bacteria or microflagellates as a major food source for marine ciliates: possible implications for the microzooplankton. Mar Ecol Prog Ser 64:147-155

Borsheim KY, Bratbak G (1987) Cell volume to cell carbon conversion factors for a bacterivorous Monas sp. enriched from seawater. Mar Ecol Prog Ser 36:171-175

Corliss JO, Snyder RA (1986) A preliminary description of several new ciliates from the Antarctica, including Cohnilembus grasseı $n$. sp. Protıstologica 22:39-46

Cowles TJ, Desıderio RA, Neuer S (1993) In situ characterization of phytoplankton from vertical profiles of fluorescence emission spectra. Mar Biol 11.5:217-222

Dale T, Dahl E (1987) Mass occurrence of planktonic oligotrichous ciliates in a bay in southern Norway. J Plankton Res 9:871-879

Davis CS, Flierl GR, Wiebe PH, Franks PJS (1991) Micropatchiness, turbulence and recruitment in the plankton. $J$ mar Res 49:109-151

Derenbach JH, Astheimer H, Hansen HP, Leach H (1979) Vertical microscale distribution of phytoplankton in relation to the thermocline. Mar Ecol Prog Ser 1:187-193

Dolan JR (1991) Microphagous ciliates in mesohaline Chesapeake Bay waters: estimates of growth rates and consumption by copepods. Mar Biol 111:303-309

Fenchel T (1974) Intrinsic rate of natural increase: the relationshup with body size. Oecologia 14:317-326

Fenchel T (1986) Protozoan filter feeding. In: Corliss JO, Patterson DJ (eds) Progress in protistology, Vol 1. Biopress Ltd, Bristol, p 66-113

Fenchel T (1987) Ecology of protozoa, the brology of freeliving phagotrophic protists. Springer-Verlag, New York

Fenchel T, Jonsson PR (1988) The functional biology of Strombidium sulcatum, a manne oligotnch ciliate (Cillophora, Oligotrichina). Mar Ecol Prog Ser 48:1-15

Finlay BJ (1977) The dependence of reproductive rate on cell size and temperature in freshwater ciluated protozoa Oecologla 30:75-81

Finlay BJ (1978) Community production and respiration by cllated protozoa in the benthos of a small eutrophic loch Freshwat Biol 8:327-341 
Franks PJS (1995) Thin layers of phytoplankton: a model of formation by near-inertial wave shear. Deep Sea Res 42: $75-91$

Frost BW (1972) Effects of size and concentration of food particles on the feeding behavior of the marine planktonic copepod Calanus pacificus. Limnol Oceanogr 17 : $805-815$

Gifford DJ (1985) Laboratory culture of marine planktonic oligotrichs (Ciliophora, Oligotrichida). Mar Ecol Prog Ser $23: 57-267$

Haigh R, Taylor FJR (1991) Mosaicism of microplankton communities in the northern Strait of Georgia, British Columbia. Mar Biol 110:301-314

Haigh R, Taylor FJR, Sutherland TE (1992) Phytoplankton ecology of Sechelt Inlet, a fjord system on the British Columbia coast. I. General features of the nano- and microplankton. Mar Ecol Prog Ser 89:117-134

Holling CS (1959) Some characteristics of simple types of predation and parasitism. Can Entomol 41:385-399

Jackson KM, Berger J (1984) Survival of ciliated protozoa under starvation conditions and at low bacterial levels Microb Ecol 10:47-59

Jackson KM, Berger $I$ (1985) Survivorship curves of ciliated protozoa under starvation conditions and at low bacterial levels. Protistologica 21:17-24

Jerome CA, Montagnes DJS, Taylor FJR (1993) The effect of the quantitative protargol stain and Lugol's and Bouin's flxatives on cell size: a more accurate estimate of ciliate species biomass. J eukaryot Microbiol 40:254-258

Jonsson PR (1986) Particle size selection, feeding rates and growth dynamics of marine planktonic oligotrichous ciliates (Ciliophora: Oligotrichina). Mar Ecol Prog Ser 33: 265-277

Jonsson PR (1994) Tidal rhythm of cyst formation in the rock pool ciliate Strombidium oculatum Gruber (Cilophora, Oligotrichida): a description of the functional biology and analysis of the tidal synchronization of encystment. J exp mar Biol Ecol 175:77-103

Kim YO, Taniguchi A (1995) Excystment of the oligotrich ciliate Strombidium conicum. Aquat microb Ecol 9:149-156

Laval-Peuto M, Rassoulzadegan F (1988) Autofluorescence of marine planktonic Oligotrichina and other ciliates. Hydrobiologia 159:99-110

Leakey RJG, Burkill PH, Sleigh MA (1994) Ciliate growth rates from Plymouth Sound: comparison of direct and indirect estimates. J mar biol Ass UK 74:849-861

Leegaard C (1915) Untersuchungen über einige Planktonciliaten des Meeres. Nytt Mag Naturvidensk 53:1-37

Lochte K (1991) Protozoa as makers and breakers of marine aggregates. In: Reid PC, Turley CM, Burkill PH (eds) Protozoa and their role in marine processes. NATO ASI publication, Springer-Verlag, New York, p 237-246

Lynn DH, Montagnes DJS (1988) Taxonomic description of some conspicuous species of strobilidine ciliates (Ciliophora: Choreotrichida) from the Isles of Shoals, Gulf of Maine. J mar biol Ass UK 68:639-658

Lynn DH, Montagnes DJS (1991) Global production of heterotrophic marine planktonic ciliates. In: Reid PC, Turley $\mathrm{CM}$, Burkill PH (eds) Protozoa and their role in marine processes. NATO ASI publication, Springer-Verlag, New York, p 281-307

Martin AJ, Montagnes DJS (1993) Winter ciliates and their putative prey in a British Columbian fjord: with descriptions of six species. J eukaryot Microbiol 40:535-549

Martinez EA (1980) Sensitivity of marine ciliates (Protozoa, Ciliophora) to high thermal stress. Estuar coast mar Sci 10: 369-381
Montagnes DJS (1993) An investigation of the growth and feeding responses of oligotrich ciliates to food types and concentrations: an approach to assessing the potential of marine planktonic ciliate blooms. PhD thesis, Univ Britısh Columbia, Vancouver

Montagnes DJS, Berges JA, Harrison PJ, Taylor FJR (1994) Estimating carbon, nitrogen, protem and chlorophyll a from volume in marine phytoplankton. Limnol Oceanogr 39:1044-1060

Montagnes DJS, Lynn DH, Roff JC, Taylor WD (1988a) The annual cycle of heterotrophic planktonic ciliates in the waters surrounding the Isles of Shoals, Gulf of Maine: an assessment of their trophic role. Mar Biol 99:21-30

Montagnes DJS, Lynn DH, Stoecker DK, Small EB (1988b) Taxonomic descriptions of one new and redescription of four species in the family Strombidiidae (Cíliophora, Oligotrichida). J Protozool 35:189-197

Montagnes DJS, Taylor FJR (1994) The salient features of five marine ciliates in the class Spirotrichea (Oligotrichia), with notes on their culturing and behaviour. J eukaryot Microbiol 41:569-586

Montagnes DJS, Taylor FJR, Lynn DH (1990) Strombidium inclinatum $\mathrm{n}$. $\mathrm{sp}$. and a reassessment of Strombidium sulcatum Claparède and Lachmann (Ciliophora). J Protozool 37:318-323

Müller $H$ (1989) The relative importance of different clliate taxa in the pelagic food web of Lake Constance. Microb Ecol 18:261-273

Müller $\mathrm{H}$, Geller W (1993) Maximum growth rates of aquatic ciliated protozoa: the dependence on body size and temperature reconsidered. Arch Hydrobiol 126:315-327

Nielsen TG, Kiørboe $T$ (1994) Regulation of zooplankton biomass and production in a temperate coastal zone. Limnol Oceanogr 39:508-519

Nielsen TG, Kiørboe T, Bjørnsen PK (1990) Effect of Chrysochromulina polylepis subsurface bloom on the plankton community. Mar Ecol Prog Ser 62:21-35

Nielsen TG, Lokkegaard B, Richardson K, Pedersen FB, Hansen L (1993) Structure of plankton communities in the Dogger Bank area (North Sea) during a stratified situation. Mar Ecol Prog Ser 95:115-131

Ohman MD, Snyder RA (1991) Growth kinetics of the omnivorous oligotrich ciliate Strombidium sp. Limnol Oceanogr 36:922-935

Owen RW (1989) Microscale and finescale variations of small plankton in coastal and pelagic environments. J mar Res 47:197-240

Rassoulzadegan F (1982) Dependence of grazing rate, gross growth efficiency and food size range on temperature in a pelagic oligotrichous ciliate Lohmanniella spiralis Leeg. fed on naturally occurring particulate matter. Annls Inst Oceanogr 58:77-184

Rassoulzadegan F, Laval-Peuto M, Sheldon RW (1988) Partitioning of the food ration of marine ciliates between picaand nanoplankton. Hydrobiologia 156:75-88

Reid PC (1987) Mass encystment of a planktonic oligotrich ciliate. Mar Biol 95:221-230

Repak AJ (1983) Suitability of selected marine algae for growing the marine heterotrich ciliate Fabrea salina. J Protozool 30:52-54

Riebesell U (1991) Particle aggregation during a diatom bloom. II. Biological aspects. Mar Ecol Prog Ser 69: 281-291

Rivier A, Brownlee DC, Sheldon RW, Rassoulzadegan F (1985) Growth of microzooplankton: a comparatjve study of bactivorous zooflagellates and ciliates. Mar microb Food Webs 1:51-60 
Ruxton GD, Gurney WSC (1994) Deriving the functional response without assuming homogeneity. Am Nat 144: $537-541$

Scott JM (1985) The feeding rates and efficiencies of a marine ciliate, Strombidium sp., grown under chemostat steadystate conditions. J exp mar Biol Ecol 90:81-95

Sheldon RW, Nival P, Rassoulzadegan F (1986) An experimental investigation of a flagellate-ciliate-copepod food chain with some observations relevant to the linear biomass hypothesis. Limnol Oceanogr 31:184-188

Silver MW, Gowing MM, Brownlee DC, Corliss JO (1984) Ciliated protozoa associated with oceanic sinking detritus. Nature 309:246-248

Skogstad A, Granskog L, Klaveness D (1987) Growth of freshwater ciliates offered planktonic algae as food. J Plankton Res 9:503-512

Smetacek V (1981) The annual cycle of protozooplankton in Kiel Bight. Mar Biol 63:1-11

Smetacek V (1984) Growth dynamics of a common Baltic protozooplankter: the ciliate genus Lohmanniella. Limnologica 15:371-376

Stoecker DK, Davis HL, Anderson DM (1984) Fine scale spatial correlations between planktonic ciliates and dinoflagellates. J Plankton Res 6:829-842

Stoecker DK, Michaels AE (1991) Respiration, photosynthesis and carbon metabolism in planktonic ciliates. Mar Biol 108:441-447

Stoecker DK, Michaels AE, Davis LH (1987) Large proportion of marine planktonic ciliates found to contain functional chloroplasts. Nature 326:790-792

This article was presented by D. K. Stoecker (Senior Editorial Advisor), Cambridge, Maryland, USA
Stoecker DK, Silver MW (1990) Replacement and aging of chloroplasts in Strombidium capitatum (Ciliophora: Oligotrichida). Mar Biol 107:491-502

Stoecker DK, Silver MW, Michaels AE, Davis LH (1988/1989) Enslavement of algal chloroplasts by four Strombidium spp. (Ciliophora, Oligotrichida). Mar microb Food Webs 3:79-100

Taniguchi A, Takeda Y (1988) Feeding rate and behavior of the tintinnid ciliate Favella taraikaensis observed with a high speed VTR system. Mar microb Food Webs 3:21-34

Tiselius P, Jonsson PR, Verity PG (1993) A model evaluation of the impact of food patchiness on foraging strategy and predation risk in zooplankton. Bull mar Sci 53:247-264

Tumantseva NI, Kopylov AI (1985) Reproduction and production rates of planktonic infusoria in coastal waters of Peru. Oceanology 25:390-394

Verity PG (1985) Grazing, respiration, excretion, and growth rates of tintinnids. Limnol Oceanogr 30:1268-1282

Verity PG (1991) Measurement and simulation of prey uptake by marine planktonic ciliates fed plastidic and aplastidic nanoplankton. Limnol Oceanogr 36:729-750

Verity PG, Villareal TA (1986) The relative food value of diatoms, dinoflagellates, flagellates and cyanobacteria for tintinnid ciliates. Arch Protistenkd 131:71-84

Wailes GH (1929) Marine ciliates of the genus Laboea from British Columbia with description of a new species. Annls Protistol 2:125-126

Wickham SA, Gilbert JJ, Berninger UG (1993) Effects of rotifers and ciliates on the growth and survival of Daphnina. J Plankton Res 15:317-334

Manuscript first received: April 11, 1995

Revised version accepted: July 21, 1995 